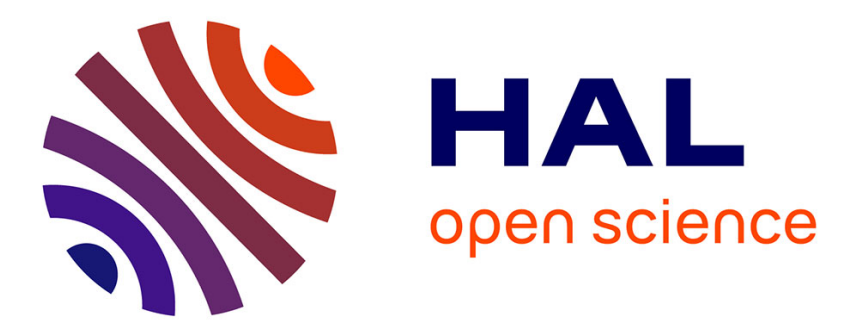

\title{
The subfossil tree deposits from the Garonne Valley and their implications on Holocene alluvial plain dynamics
}

\author{
Jean-Michel Carozza, Laurent Carozza, Philippe Valette, Muriel Llubes,
} Vanessa Py, Didier Galop, Mihaela Danu, Laurie Ferdinand, Mélodie David, Laurent Sévègnes, et al.

\section{To cite this version:}

Jean-Michel Carozza, Laurent Carozza, Philippe Valette, Muriel Llubes, Vanessa Py, et al.. The subfossil tree deposits from the Garonne Valley and their implications on Holocene alluvial plain dynamics. Comptes Rendus Géoscience, 2014, pp.8. halshs-01069926

\section{HAL Id: halshs-01069926 \\ https://shs.hal.science/halshs-01069926}

Submitted on 30 Sep 2014

HAL is a multi-disciplinary open access archive for the deposit and dissemination of scientific research documents, whether they are published or not. The documents may come from teaching and research institutions in France or abroad, or from public or private research centers.
L'archive ouverte pluridisciplinaire HAL, est destinée au dépôt et à la diffusion de documents scientifiques de niveau recherche, publiés ou non, émanant des établissements d'enseignement et de recherche français ou étrangers, des laboratoires publics ou privés. 


\title{
The subfossil tree deposits from the Garonne Valley and their implications on Holocene alluvial plain dynamics
}

\author{
Jean-Michel Carozza*, Laurent Carozza, Philippe Valette, Muriel Llubes, \\ Vanessa Py, Didier Galop, Mihaela Danu, Laurie Ferdinand, Mélodie David, \\ Laurent Sévègnes, Laurent Bruxelles, Marc Jarry, Francis Duranthon
}

University of Strasbourg (UDS), Department of Geography, 3, rue de l'Argonne, 67083 Strasbourg cedex, France

\section{A R T I C L E I N F O}

\section{Article history:}

Received 22 January 2014

Accepted after revision 31 January 2014

Available online $\mathrm{xxx}$

\section{Keywords:}

Subfossil trunk

Black oak

Garonne

Holocene

Alluvial plain

France

\begin{abstract}
A B S T R A C T
Subfossil tree trunks deposits are common in large rivers, but their status as a source for dating alluvial sequences and palaeoenvironmental studies is still discussed. Particularly their origin and the process(es) of deposition as well as a possible remobilization were pointed as a limit to their use to document river alluvial changes. In this work we report the discovery of the largest subfossil trunks deposits in the Garonne valley. These new data are compared to the previous ones. A set of 17 tree trunks and more than 300 smaller wood fragments were collected. The xylologic study shows the prevalence of Quercus and a single occurrence of Ulmus. These two hardwood species are commonly associated with riparian forest. The ${ }^{14} \mathrm{C}$ dating carried out on seven trunks and a single branch of Quercus on the outermost identified growth rings, indicates age ranging from $8400-8000 \mathrm{cal}$. BP for the oldest fragment (bough) to $4300-4000 \mathrm{cal}$. BP for the most recent tree trunk. Radiocarbon ages of the trunks are aggregated into two main periods: 5300-5600 cal. BP (four trunks) and 4300-4000 cal. BP (three trunks). The radiocarbon (charcoal) dating of the top of the alluvial sequence overlaying the trunks gives an age between 1965-1820 and $1570-1810 \mathrm{cal}$. BP, i.e. between the 2 nd and the 5 th c. AD. In addition, the discovery of two unpublished subfossil tree trunks deposits in Finhan are reported (six trunks). At the light of these results, we discuss previously proposed models for the Garonne floodplain building.
\end{abstract}

(C) 2014 Académie des sciences. Published by Elsevier Masson SAS. All rights reserved.

\section{Introduction}

Alluvial fossil and subfossil tree trunks are of great interest to document formation, evolution and destruction of the riparian forest vegetation in order to characterize palaeo-ecosystems as once more highlighted (Finsinger et al., 2013; Lézine et al., 2013) but also as a source to constrain alluvial valley building processes (Becker, 1993; Leuschner, 1992).

\footnotetext{
* Corresponding author.

E-mail address: jmcarozza@yahoo.fr (J.-M. Carozza).
}

Subfossil tree trunks are frequent in Post-glacial alluvial infills of temperate and central European rivers (Danube River, Becker, 1975; Vistula River, Kalicki and Krapiec, 1995; Starkel, 1995; Warta River, Dzieduszynska and Petera-Zganiacz, 2012; Maine River, Becker and Schirmer, 1977; Morava River, Kolar and Ribnicek, 2011; Middle Rhine River, Striedtler, 1988; Tegel et al., 1999; Rhône River, Bravard, 1986; Salvador, 1991). The tree trunks are called subfossils as if they are old trees, they still mainly consist of lignin and cellulose. Their dark colour is related to the interaction between the water ferrous compounds and the tannins of the matter (van Bürck et al., 2012). Quercus is the most common species found in the alluvial deposits but other hardwood species can also be found: 
alder, ash, maple, beech. More rarely, softwood species also exist: pine, lime. . Quercus overrepresentation is related to taphonomic processes rather than to the ecological composition of the riparian forests (Leuschner, 1992). Once dead, tree trunks can be stored in the floodplain and preserved for millennia (Becker, 1993).

The use of subfossil tree trunks for the dating alluvial sequences is hugely dependent on the nature of the deposit. If subfossil tree trunks are in situ, i.e. upright and rooted, their chronostratigraphic is clearly established as palaeosol. In this case, usually, only the rooted strains are found. The same is not true for subfossil trees found unrooted. These tree trunks can be longer and reach more than twenty meters long. These tree trunks may have experienced a complex history between the time of their death and their final incorporation into the sedimentary record. In this sense, subfossil tree trunks must be considered as specific component of the sedimentary load, with it specific transfer time within the fluvial system. The correlation with transfer time of sediments of various granulometry (Chabaux et al., 2012) or with the fluvial pattern (Schumm, 1977) is currently poorly documented. Kalicki and Krapiec (1995) suggested that once the tree trunks fall in the channel, they can be buried in situ or transported and reworked within the river channel. Distinguishing between these two situations in the field is often impossible and only absolute $\left({ }^{14} \mathrm{C}\right)$ or relative (dendrochronology) dating provides reworking evidences. The chronostratigraphic meaning of unrooted subfossil trees is then more difficult to establish. The time gap separating the age of the oldest tree from the youngest one could be considered as an indicator of the complexity of the tree trunk deposits history. Indeed, homogeneous deposits from a chronological point of view would reflect the rapid burial of tree trunks by one or a set of major floods, while heterogeneous one reflects at least one stage of storageerosion and mixing with younger trunks. However, the clustering of dates $\left({ }^{14} \mathrm{C}\right.$ or dendrochronological) into two sets can also be the result of the accumulation processes. Kalicki and Krapiec (1995) have shown that the tree trunks can be transported by different ways: flotation for light weight woods-the recent dead tree trunks not yet waterlogged-or as bedload for heavy weight woodsthe older waterlogged and reworked tree trunks. The coexistence of these two processes leads to the apparent stratification (pseudo-stratification) of subfossil trees in meandering rivers. Thus, the use in the alluvial context of subfossil tree trunks as chronological markers needs a good understanding of the deposit and must be based on multiple dating.

In the case of the Garonne valley, little attention has been paid prior to this study to subfossil tree trunks discovered by chance. Up to now, only two small deposits have been published (Fig. 1) in Muret, upstream of Toulouse (Bourgeat et al., 1984), and in Golfech, in the middle reach of the Garonne (Rieucau, 1971). In spite of the scarcity of these data, they were used to propose a stratigraphical model of the floodplain building by downstream progradation (Bourgeat et al., 1984). According to these authors, the floodplain of the Garonne River is older (i.e. Pleniglacial) in its upper course and younger (Late
Glacial to Early Holocene) in its lower part. The Pleniglacial age of the upper floodplain is inferred by: (1) the geomorphological correlation with the terminal moraines of the Garonne valley in Barbazan basin (La Serre and Valcabrère-Labroquère moraines); (2) the discovery of Elephas Trogontherii in the Palaminy gravel pit excavating the Fz1 alluvial level (Méroc, 1967, figure 1); and (3) the decreasing age of subfossil tree trunks in the downstream direction. More, this model could account for the chronological contradictions of the former works. Indeed, Hubschman $(1972,1975)$ dated the Garonne floodplain upstream of Toulouse Pleniglacial in age (Hubschman, 1972, 1975), while the reach downstream of Toulouse is attributed to the Holocene by Enjalbert (1960) and Cavaillé (1965, 1969).

In this work we report on the discovery of the largest deposit ever encountered in the Garonne valley close to Bourret and propose a review of published and unpublished data on subfossil tree trunks. On this basis, we refine the sketch of evolution of the Garonne floodplain formation between Toulouse and the Tarn River junction. We highlight the relevant consequences of these radiocarbon dates on the timing and process of the Garonne valley building downstream from Toulouse.

\section{The study area}

The Garonne River is the fourth French river by its length $(647 \mathrm{~km})$ and size of its watershed $\left(55,000 \mathrm{~km}^{2}\right)$. The Middle Garonne corresponds to the reach between the Ariège and Tarn Rivers confluences (Fig. 1, Lambert, 1989; Valette, 2002). It is characterised by: (i) a high valley slope value, up to $0.6 \%$; (ii) the drift of the river flow from a south-north direction to a SE-NW direction; (iii) the floodplain widening from less than $2 \mathrm{~km}$ to up than $4.5 \mathrm{~km}$ in average; and (iv) the migration of the riverbank erosion from the right bank to the left bank as the valley direction curve. Given its geographical position between oceanic and Mediterranean influences, the Garonne has a complex flow regime (Lambert, 1989; Pardé, 1935). Its hydrologic regime is characterised by rainfall and snowmelt runoff origin and high mean runoff value $\left(631 \mathrm{~m}^{3} \mathrm{~s}^{-1}\right)$. The so-called Pyrenean oceanic floods generate outflow up to $8500 \mathrm{~m}^{3} \mathrm{~s}^{-1}$ (i.e. 1875 flood) while pure oceanic one, from Massif Central origin, reaches only $\left(6700 \mathrm{~m}^{3} \mathrm{~s}^{-1}\right.$ in Tonneins during 1927 flood). The largest floods are from southern Massif Central (The Tarn River, $8300 \mathrm{~m}^{3} \mathrm{~s}^{-1}$ during 1930 flood) and have a Mediterranean origin. These latest floods do not affect the section described here.

The gravel pit of Bourret is located close to the current channel of the Garonne River (Fig. 1) downstream from a series of naturally or artificially abandoned meanders (Valette, 2002). There, the floodplain is relatively narrow ( $2.7 \mathrm{~km}$ wide). The river is offset to the west flank of its valley, and carve into the Tertiary sandstone. Lambert's geomorphological map (Lambert, 1989) distinguished three alluvial levels according to their flood frequency (resp. Fz1, Fz2 and Fz3) that could be correlated with distinct alluvial levels. According to the geological map (BRGM, 2001), the pit is located in the Fz3 alluvial unit. No chronological data is available in this area for the Late 


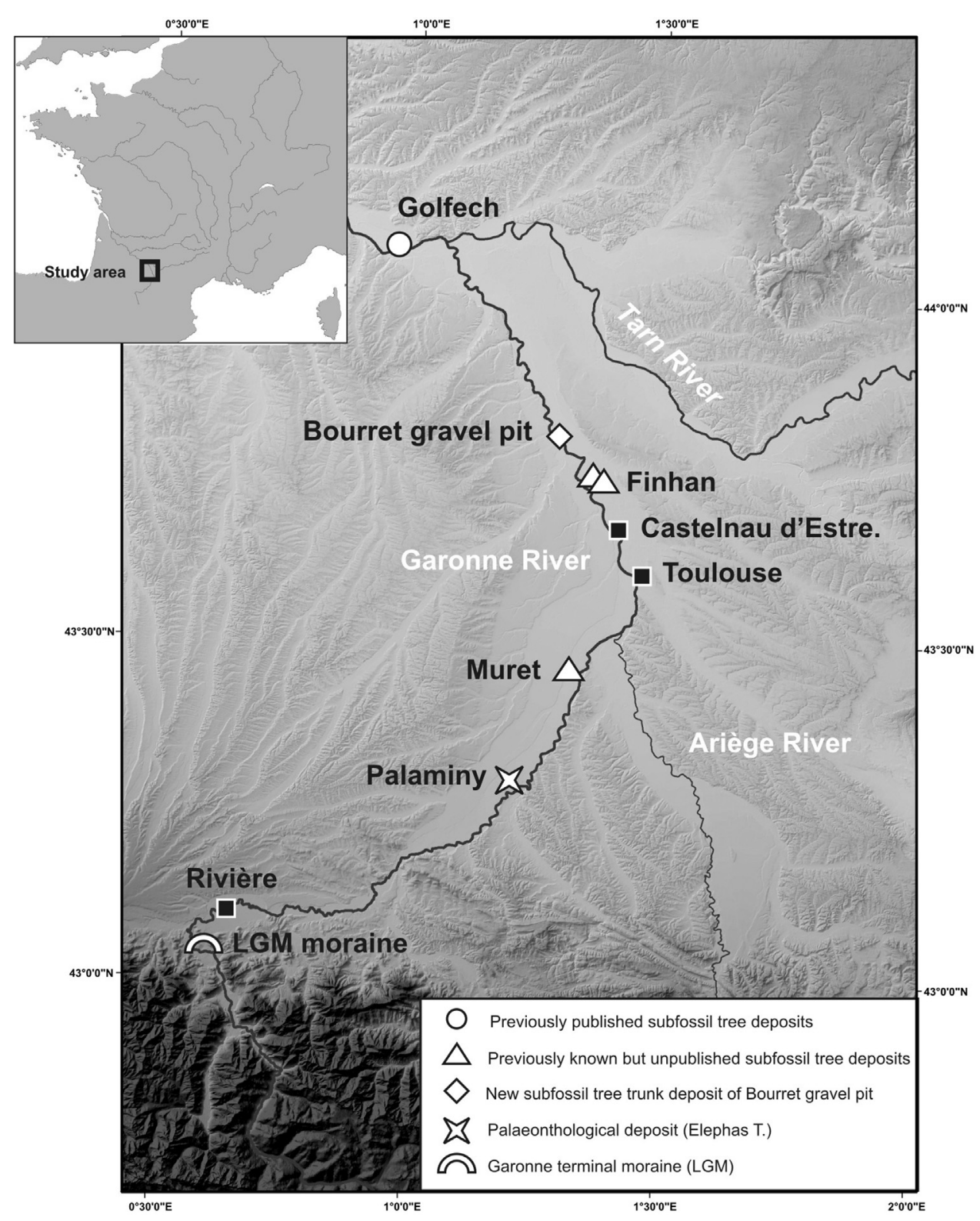

Fig. 1. Map of the study area and location of the places mentioned in the text. Topographic data are from IGN (BD Alti, $25 \mathrm{~m}$ ).

Glacial to Holocene alluvial formations. Results obtained by Bruxelles et al. (2010) and Carozza et al. (2013) in the South of the Middle Garonne suggest that Fz1 is dated between the Late Glacial to the middle part of the first Holocene (c. $8900 \mathrm{cal}$. BP) and Fz2 from the second part of the Holocene (post 4400 cal BP). The age of the Fz3 unit is unknown in this area.

According to geotechnical data, the Fz3 unit reaches 7 to $9 \mathrm{~m}$ of thickness and is mainly composed of gravel (3 to $6 \mathrm{~m}$ ) at its base and of sand and silt at its top (from 1 to $5 \mathrm{~m}$ ).

\section{Study methods}

The pit gravel of Bourret was systematically surveyed on several occasions. The subfossil tree trunks deposit consists of seventeen tree trunks, some reaching over $15 \mathrm{~m}$ in length and more than $1.4 \mathrm{~m}$ in diameter. They were collected during two field campaigns, out of their sedimentary context as they were removed from the extraction pit by the operator. The location of the tree trunks and their burial depth were estimated according to the information provided by the operator for each tree trunk. The burying depth ranges from 6 to $9 \mathrm{~m}$. Entire tree trunks sections were sampled to proceed to their radiocarbon dating and dendrochronological study. In addition, all wood fragments more than $5 \mathrm{~cm}$ long were systematically collected to provide a first evaluation of the specific taphonomy of the tree trunks. More than 300 wood fragments were picked up. The identification of the tree trunks and wood fragments was performed on wood chips 


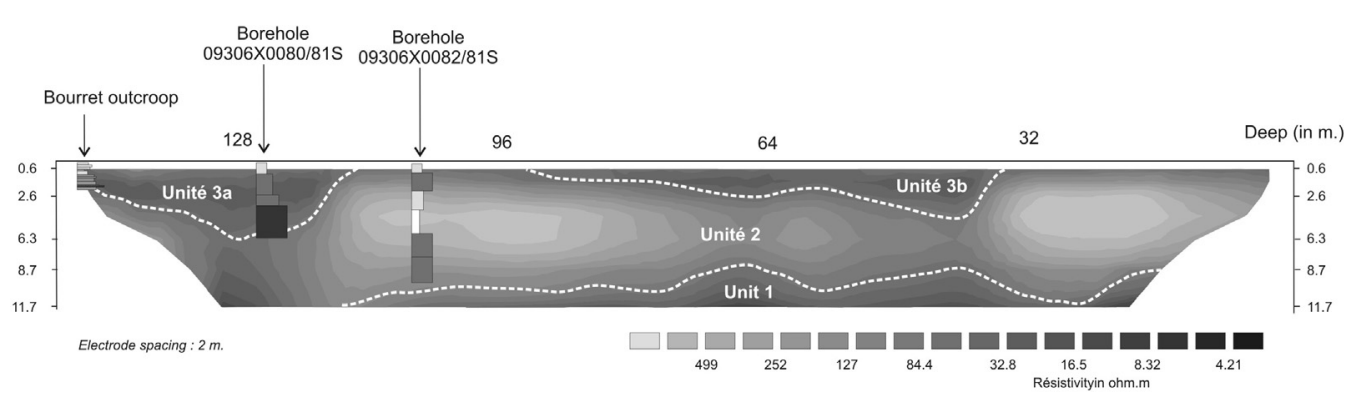

Fig. 2. ERT profile close to the Bourret gravel pit (electrode spacing: $2 \mathrm{~m}$ ). Boreholes are from BRGM (BSS, access online: http://infoterre.brgm.fr/).

mounted between slide and slip cover. The samples show altered and deformed anatomical structures (cell collapse) related to pre-burying alteration and alternated humidification-desiccation periods during post-burial time. In addition, calcitic inclusions are abundant, and the wood structure is partly mineralized, leading to difficulties in species identification.

Radiocarbon dating was performed on the external tree rings for each one of the tree trunks (three to five tree rings for each individual). Because of scratching and abrasion by bedload during transport, the sapwood is missing on tree trunks, and it is not possible to provide a cambial age. The ${ }^{14} \mathrm{C}$ ages of subfossil tree trunks are generally underestimated by around 25 years (Szepertyski, pers. com.).

According to its position close to the tree trunks deposit, a sedimentary cross-section was chosen. To complete these observations, two ERT profiles located on the same place, but with different electrodes spacing (resp. 1 and 2 m, Figs. 2 and 3), were made. We used these data to complete the observation of the deeper part of the floodplain, which contains subfossil trees that cannot be observed directly due to the watertable height. In addition

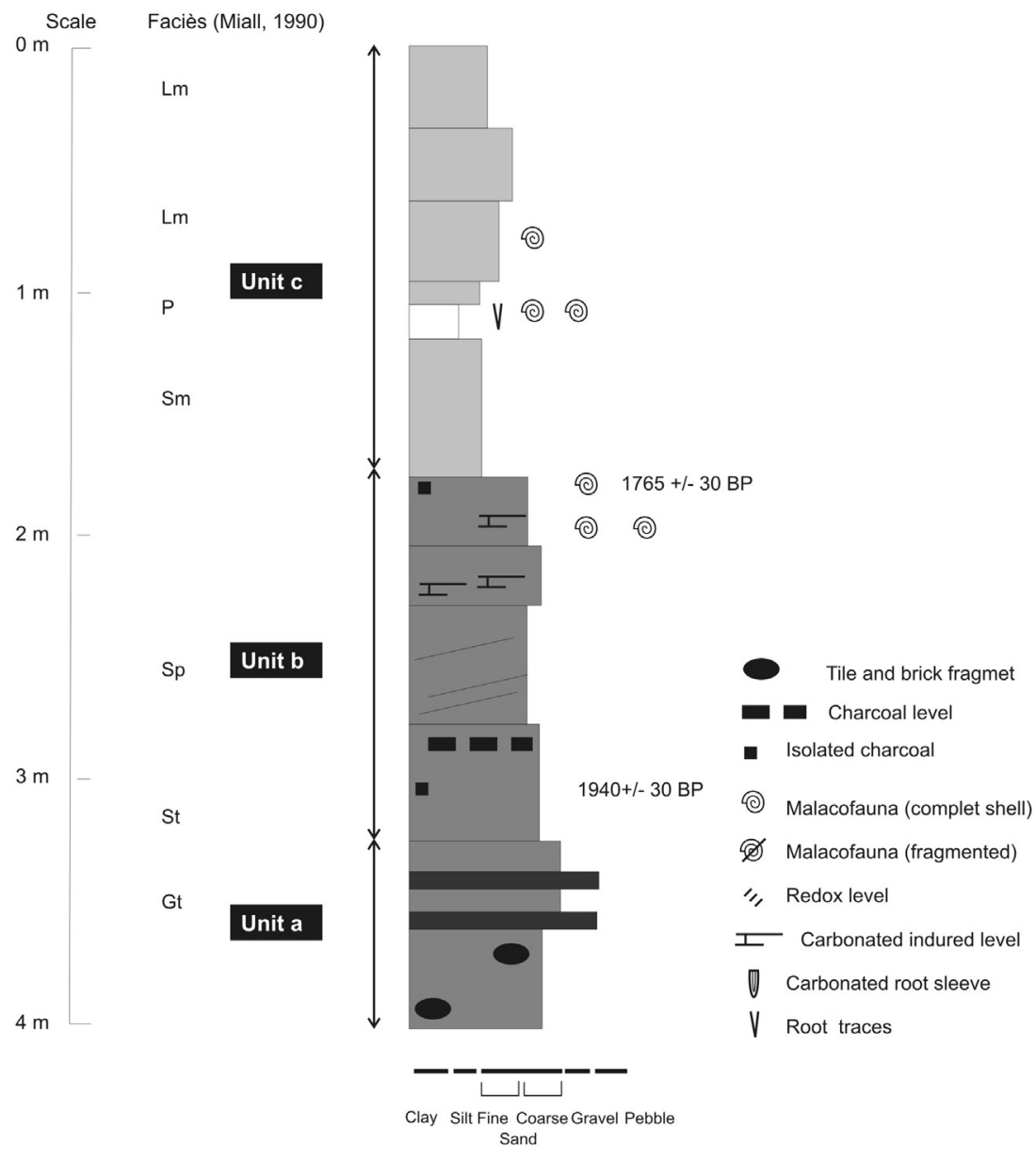

Fig. 3. Stratigraphic section of the upper part of the Bourret alluvial sequence. 
and to cross-validate these data, boreholes from the French geological database (BSS from BRGM), were also used despite the paucity and vagueness of data it contains. Only seven boreholes are available for this area.

\section{Results}

\subsection{General stratigraphic organisation of the alluvial sequence}

An overview on the whole sequence stratigraphy is provided by the ERT profiles (Fig. 2). The low-resolution profile (electrodes spacing $2 \mathrm{~m}, 124 \mathrm{~m}$ length) reached the molassic bedrock, a less than $30 \Omega \mathrm{m}$ unit, at a depth varying between 9 to $13 \mathrm{~m}$ (Unit 1 ). The thickness of Unit 2 varies from 5 to $10 \mathrm{~m}$ depending on both the shape of its base and the bottom of the upper unit (Unit 3). Unit 2 has a high resistivity comprised between 130 and $700 \Omega \mathrm{m}$ that is compatible with a detrital origin (sand and gravel). At the top, Unit 3 is composed of low-resistivity materials (130 to $16 \Omega \mathrm{m}$ ). The thickness of this unit varies between 0.5 and $6 \mathrm{~m}$ and shows a lens-shaped organisation, with two maxima at 40 and $125 \mathrm{~m}$ from the beginning of the profile (resp. Unit $3 a$ and $3 b$ ).

The data from the BRGM's BSS confirm these interpretations. The 09306X0081/81S drilling (Fig. 3) has intersected Unit $3 a$ and encountered channel facies associations at its bottom (pebbles and gravel) and marginal to channel abandonment facies (sand and silt) at its top. By contrast, the 09306X0082/81S drilling, which cuts Unit 2, shows the absence of gravel channel deposits and intersected only floodplain alluvial facies (sand, silt and clay). The direct observation on the field section also shows the dominance of sandy to silty clay facies in this unit.

The reference section, ca. $4.0 \mathrm{~m}$ height, located at the northeastern corner of the gravel pit (Fig. 3) shows the vertical succession from natural-levee and proximal flood plain (medium to coarse sands with planar stratification, sometimes slightly oblique, units a and b) to distal floodplain deposits (fine sands and silts with intercalated stratified planar palaeosol, unit c) on its top. These data are consistent with the geophysical one and allow us to interpret the sequence as meander-like palaeochannels and associated flood plain.

\subsection{Radiocarbon dating of the deposit}

The understanding of tree trunk deposit formation process and its signification is based on eight ${ }^{14} \mathrm{C}$ dates measured on subfossil wood (seven trunks and one isolated branch) and two ${ }^{14} \mathrm{C}$ dates performed on macrocharcoal sampled in the alluvial sequence. The artefacts content of the sequence is also taken in consideration. All radiocarbon data are reported in Table 1.

The dates obtained on subfossil wood aggregate into three groups (Table 1). The first one is represented by the isolated date performed on the branch fragment. It gave the older date of the deposit, ca. $8000-8400$ cal. BP. The second group includes four tree trunks and form a very homogeneous cluster ca. $4950 \mathrm{cal}$. BP. The third set consists of three individuals whose dates are centred ca. 4150 cal. BP. Therefore, the Bourret subfossil tree trunks deposit is heterogeneous and diachronous. It comprised individuals whose death is spread over a period of about 4000 years. Additional information on the alluvial formation is provided by dating performed on the sedimentary sequence.

Based on radiocarbon dating, the top of the formation that corresponds to the final stage of the palaeochannel infilling is assigned to the 2 nd and 4th century AD. The artefacts collected in the coarse upper sequence include large amount of rolled brick and flat tile from the Roman Antiquity period. It suggests that the Unit 3 must be reported to the Roman era sensu lato. These elements allow a discussion on the dynamics of the formation of the deposit and the floodplain architecture.

\section{Discussion}

The dates obtained on seven trunks and a branch fragment show the diachronicity of the Bourret subfossil tree trunks deposit, which spans at least over more than four millennia. This remark leads to consider carefully the earlier dating of the alluvial sequences proposed in the Garonne valley and their geomorphological implications (see below).

Two interpretations of the Bourret sequence can be proposed (Fig. 4): (i) the complete alluvial sequence (Units 2 , 3a and $3 \mathrm{~b}$ ) is dated from the Roman period and all subfossil tree trunks were reworked at least one time. In

Table 1

Table of the radiocarbon dates (this work).

\begin{tabular}{|c|c|c|c|c|}
\hline Place & Dated material & Lab number & Age BP & Age cal. BP 2s \\
\hline Bourret-Branch 1 & Branch Quercus & Beta - 282416 & $7380 \pm 40$ & $8320-8070$ \\
\hline Bourret-Tree 1 & Tree trunk Quercus & Poz-45829 & $3760 \pm 35$ & 4237-3990 \\
\hline Bourret-Tree 2 & Tree trunk Quercus & Poz-45830 & $4725 \pm 35$ & 5583-5325 \\
\hline Bourret-Tree 3 & Tree trunk Quercus & Poz-45831 & $3745 \pm 35$ & 4229-3984 \\
\hline Bourret-Tree 4 & Tree trunk Quercus & Poz-45833 & $4725 \pm 35$ & $5583-5325$ \\
\hline Bourret-Tree 5 & Tree trunk Quercus & Beta - 324046 & $4670 \pm 40$ & $5580-5310$ \\
\hline Bourret-Tree 6 & Tree trunk Quercus & Beta - 324047 & $3790 \pm 30$ & $4240-4090$ \\
\hline Bourret-Tree 7 & Tree trunk Quercus & Beta - 324048 & $4620 \pm 30$ & $5450-5300$ \\
\hline Bourret-Cross-section & Charbon ind. & Poz-42110 & $1940 \pm 30$ & $1822-1967$ \\
\hline Bourret-Cross-section & Charbon ind. & Poz-42109 & $1765 \pm 30$ & $1570-1811$ \\
\hline
\end{tabular}

All the radiocarbon dates were calibrated by us using the Calib 6.11 software (Stuiver and Reimer, 1993). 
Table 2

Previous radiocarbon dates.

\begin{tabular}{lllc}
\hline Place & Dated material & Source & Age BP \\
\hline Golfech & Tree trunk Pinus sp. & Rieucau, 1971 & $9170 \pm 110$ \\
Golfech & Tree trunk Pinus sp. & Rieucau, 1971 & $8900 \pm 160$ \\
Muret & Tree trunk & Bourgeat et al., 1984 & $10,665-10,150$ \\
Muret & Tree trunk & Bourgeat et al., 1984 & $10,370-9545$ \\
Finhan & Tree trunk Quercus sp. & Unpublished (Erl 15333) & $9320 \pm 200$ \\
\hline
\end{tabular}

All the radiocarbon dates were calibrated by us using the Calib 6.11 software (Stuiver and Reimer, 1993).

this scenario, the subfossil tree trunks are confined in channels of the Roman period and only give a terminus post quem age for the alluvial sequence. This model is difficult to reconcile with the geometry of the palaeochannel (Unit $3 a$ and $3 b$ ), which does not exceed a 6-m thickness; (ii) the alluvial sequence is composed of two diachronic units. At the bottom, Unit 2 corresponds to a conserved "old layer". Its age is given by the youngest tree trunk date, ca. 4150 cal. BP, which records the last stage of deposition of this unit. Unit 3 is dated from the Roman epoch and aggrades over Unit 2. This last stratigraphic organisation is compatible with previous observations in Castelnaud'Estretefond (Carozza et al., 2013).

These new data collected in the Bourret gravel pit complete previous data collected in the Garonne valley (Fig. 1 and Table 2). So far, only two other subfossil tree deposits were reported.

The first one is located close to Muret, upstream from Toulouse city (Bourgeat et al., 1984, Fig. 1 and Table 2). Two subfossil woods of unknown species were discovered in a gravel pit at a depth of $4 \mathrm{~m}$. Their radiocarbon dating gave ages of respectively $9790 \pm 170 \mathrm{BP}$ and $9320 \pm 200 \mathrm{BP}$ $(11,819-10,667$ and $11,196-9959$ cal. BP). Up to now, the Muret subfossil trees are the oldest dated in the Garonne valley. The second deposit was discovered downstream from the study area, close to Golfech (Fig. 1 and Table 2). A set of subfossil tree trunks were unheard-of during the digging of the cooling channel of the nuclear plant. Two subfossil trunks of Pinus have been dated $9170 \pm 110$ and $8900 \pm 160 \mathrm{BP}$, or $10,665-10,150$ and 10,370-9545 cal. BP, respectively (Rieucau, 1971). The dates obtained are slightly younger than those of the Muret deposit.

In addition, in Finhan (Fig. 1), two unpublished findings can also be reported. Some of us (Bruxelles, Jarry and Duranthon) have dated a trunk of Quercus in an abandoned pit gravel (unpublished data, Table 2). Radiocarbon dating has provided an age of $2913 \pm 47$ age or $3210-2890 \mathrm{cal}$. BP. Nearby, Szepertyski (unpublished data) have studied six

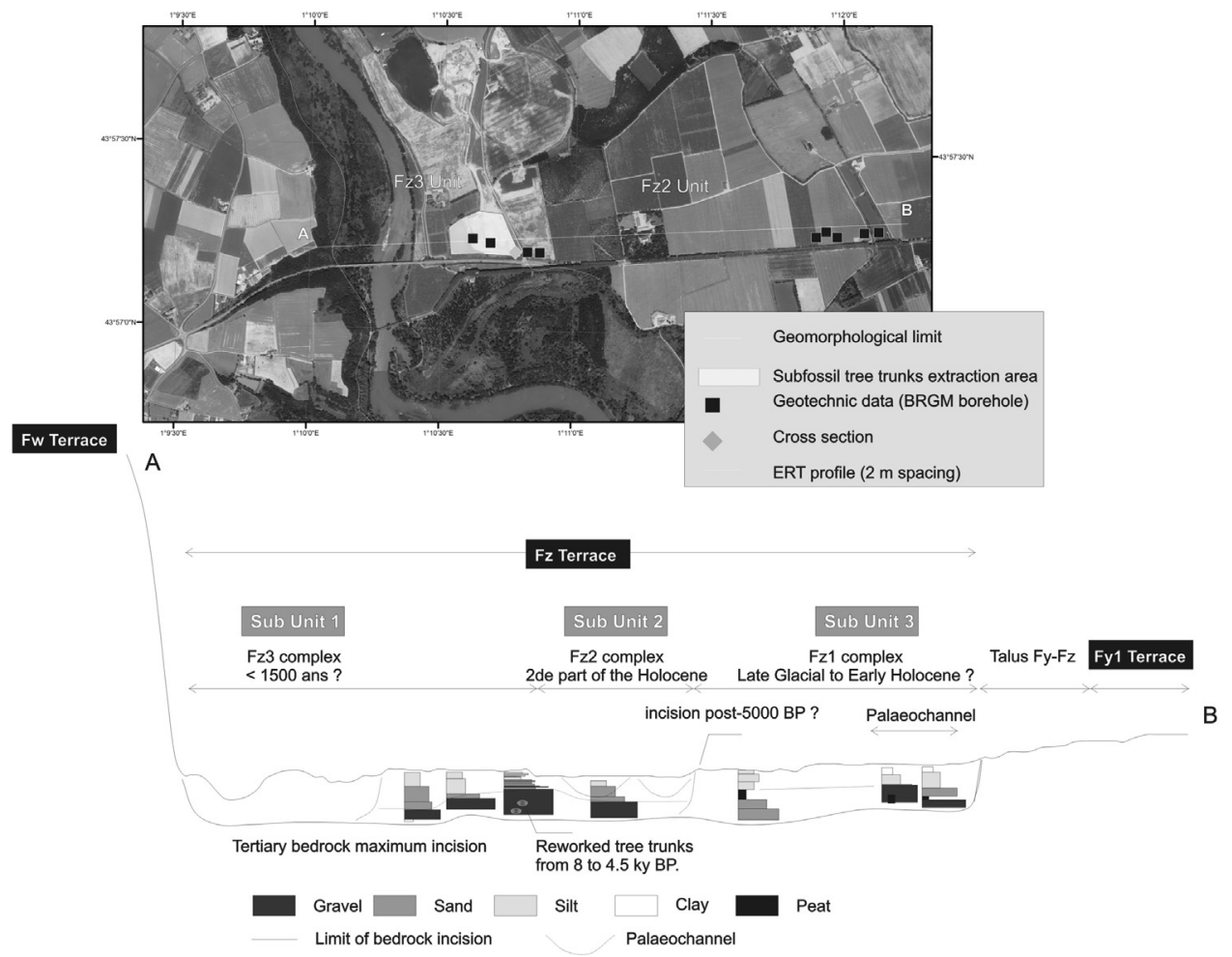

Fig. 4. Cartographic and stratigraphic interpretation of the entire cross-section of the Garonne valley close to Bourret. Topographic data are from IGN (BD Alti, $25 \mathrm{~m}$ ) and geotechnical data are from BRGM (BSS, access online: http://infoterre.brgm.fr/). 
subfossil trunks of Quercus discovered in the abandoned gravel pit of the Clos de l'îlot. According to dendrochronological data, five of the tree trunks have been synchronized and are contemporaries. The last one cannot be synchronised and is probably reworked. For synchronised trees, Szepertyski has proposed death dates ranging from 9470 to $9296 \mathrm{cal}$ BP.

These new data collected in the Middle Garonne do not match the continuous downstream progradation building model proposed by Bourgeat et al. (1984). If the upstream Muret's subfossil wood deposit remains the oldest discovered in the Garonne, the Bourret and Finhan deposits are more recent than the Golfech one. In addition, the yellow-silts (a set of fluvial to paludal sedimentary facies described by Hubschman, 1975) recently dated by Bruxelles et al. (2010) and Bruxelles and Jarry (2011) in Castelnau-d'Estretefonds (17,640-16,930 Cal. BP and $15,070-14,210$ cal. BP) do not fit with this model. Downstream to Toulouse, the Garonne floodplain appears as a complex unit built during the LGM to the Holocene. Three main stages of construction may be identified: (1) during the LGM, the yellow silt unit was deposited. This aggrading stage remains poorly documented but seems to overlap the Early Holocene (Carozza et al., 2013); (2) between ca. 8900 and 5000 cal. BP, as previously shown by the work around Castelnau-d'Estretefonds (Carozza et al., 2013). This episode is interrupted by a major phase of incision close to $5000 \mathrm{cal}$. BP; (3) between c. $2900 \mathrm{cal}$. BP to present as shown by the present results in Bourret and the previously published one in Castelnau-d'Estretefonds (Carozza et al., 2013).

By contrast, the hypothetical diachronism between the Garonne alluvial plain upstream and downstream of Muret, evidenced by the palaeontological finding of Palaminy in the Fz unit, remains an open question. In all the cases, the data on both the upstream and the downstream sector are difficult to conciliate with the Late Glacial age (14.6 ka ${ }^{10} \mathrm{Be}$ to $13.1 \mathrm{ka}{ }^{10} \mathrm{Be}$ ) proposed for the abandonment of the Fxb fluvial terrace near Rivière by Stange et al. (2014). The possible over crossing of the LGM by the Late Glacial to Early Holocene alluvial terraces downstream to Toulouse suggested by Lambert (1989) could explain this anomaly.

\section{Conclusion}

The radiocarbon dates obtained on subfossil tree trunks in dead position indicate that the deposit is heterogeneous in origin and has experienced at least one phase of reworking. There is no simple relationship between the age of the subfossil tree trunks and the age of the alluvial sequence that contain. The transfer time of this organic fraction of the alluvial sediments is difficult to correlate with the mineral fraction one. Consequently, isolated radiocarbon or dendrochronological dates obtained on this kind of deposits must be used with caution to establish a geochronological model of alluvial floodplain formation or to assess the riparian forest biodiversity because of possible mixes.

The results and data obtained in this study lead to consider with wariness previous works on subfossil tree trunks and their geochronological assumptions, as discussed here for the Garonne lower alluvial plain. Thus, the building model of the Garonne alluvial plain by a continuous downstream progradation between LGM and Holocene lapses. The stratigraphical relationship between the plain upstream and downstream of Muret remains problematic and could be explained by crossing the alluvial terraces. This hypothesis and its implications on the Aquitaine Basin evolution during the Upper Pleistocene to the Holocene remain to be investigated.

The subfossil tree trunks deposit discovered in Bourret is the most important to date in the Garonne valley. The xylologic study shows they are associated with the riparian forest re-conquest dominated by Quercus during the first part of the Holocene. However, the overrepresentation of hardwood species (Quercus or Ulmus) is a direct consequence of the deposit formation process, i.e. floodplain recycling and storage/unstorage of tree trunks in the floodplain and transport. The least resistant species (Corylus, Salix. . .) identified by palynological works during this period (Carozza et al., work in progress) probably suffered greater damage and mechanical destruction during transport phases.

\section{Acknowledgements}

The authors thank the MGM company and his staff for their assistance and cooperation during field works. This work was supported by the GAL\&ET program (French Ministry of Environment) and the Collective Research Programme of the French Ministry of Culture "Evolution of middle Garonne during the Holocene".

\section{References}

Becker, B., 1975. Dendrochronological observations on the postglacial river aggradation in the southern part of central Europe. Biuletyn Geologiczny 19, 127-136.

Becker, B., 1993. An 11,000-year German oak and pine dendrochronology for radiocarbon calibration. Radiocarbon 35, 201-213.

Becker, B., Schirmer, W., 1977. Paleoecological study on the Holocene valley development of the Maine river, southern Germany. Boreas 6, 303-321.

Bourgeat, F., Icole, M., Revel, J.-C., 1984. Les terrasses alluviales dans les Petites-Pyrénées et l'avant-pays molassique : les conditions de leur mise en place. Bull. Assoc. Fr. Etude Quat. 21 (1-3) 60-66.

Bravard, J.-P., 1986. Le Rhône, du Léman à Lyon. La Manufacture, Lyon, $451 \mathrm{p}$.

BRGM, 2001. Notice de la carte géologique de Saint-Nicolas de Lagrave, 0929. BRGM Orléans, 13 p.

Bruxelles, L., Jarry, M., 2011. Climatic conditions, settlement patterns and cultures in the Paleolithic: the example of the Garonne Valley (Southwest France). J. Hum. Evol. 61 (5) 538-548.

Bruxelles, L., Pons, F., Magnin, F., Bertrand, A., 2010. Âges et modalité de la mise en place de la couverture limoneuse de la basse plaine de la Garonne d'après l'exemple du site de Fontréal (Castelnau-d'Estrétefonds, Haute Garonne). Quaternaire 21, 339-348.

van Bürck, U., Wagner, F.E., Lerf, A., 2012. Mössbauer studies of subfossil oak. Hyperfine Interact 208, 105-110.

Carozza, J.-M., Valette, P., Carozza, L., Llubes, M., Ferdinand, L., Edou Obame, S., Sévègnes, L., 2013. L'architecture de la basse plaine de la Garonne en aval de Toulouse : premiers résultats. Quaternaire 24 (4) 455-464.

Cavaillé, A., 1965. Les unités morphologiques des basses plaines de la Garonne. Rev. Geogr. Pyr. S. O. 36 (3) 243-278.

Cavaillé, A., 1969. Les terrasses de la Garonne à l'ouest de Toulouse. Livretguide excursion A6, Pyrénées orientales et centrales, Roussillon et Languedoc occidental. $8^{\mathrm{e}}$ congrès INQUA, Paris16-23. 
Chabaux, F., Blaes, E., Granet, M., di Chiara Roupert, R., Stille, P., 2012 Determination of transfer time for sediments in alluvial plains using 238U-234U-230Th disequilibria: the case of the Ganges river system. C. R. Geoscience 344 (11-12) 688-703.

Dzieduszynska, D., Petera-Zganiacz, J., 2012. Geologic position of the Younger Dryas subfossil forest in the Warta River valley, central Poland. Bull. Geol. Soc. Finland 84, 69-79.

Enjalbert, H., 1960. Les pays aquitains. Le modelé et les sols. Thèse Imprimerie Bière, Bordeaux, 618 p.

Finsinger, W., Dos Santos, T., McKey, D., 2013. Estimating variation in stomatal frequency at intra-individual, intra-site, and inter-taxonomic levels in populations of the Leonardoxa africana (Fabaceae) complex over environmental gradients in Cameroon. C. R. Geoscience 345 (78) 350-359.

Hubschman, J., 1972. L’âge de la basse plaine garonnaise, des Pyrénées au confluent du Tarn. C. R. Acad. Sci. Paris, Ser. D 275, 651-653.

Hubschman, J., 1975. Morphogenèse et pédogenèse quaternaire dans le piémont des Pyrénées garonnaises et ariégeoises. Thèse. Université Toulouse, $745 \mathrm{p}$.

Kalicki, T., Krapiec, M., 1995. Problems of dating alluvium using buried subfossil tree trunks: lessons from the 'black oaks' of the Vistula Valley, Central Europe. Holocene 5 (2) 243-250.

Kolar, T., Ribnicek, M., 2011. Dendrochronological and radiocarbon dating of subfossil wood from the Morava River basin. Geochronometria 38 (2) $155-161$

Lambert, R., 1989. Atlas hydrogéomorphologique de la Garonne. Inédit. Leuschner, H.H., 1992. Subfossil trees. In: Bartholin, T.S., Berglund, B.E. Eckstein, D., Schweingruber, F.H., Eggertsson, O. (Eds.), Tree-rings and Environment. Proc. Int. Symp. Lundqua Report 34, Ystad, pp. 193-197.

Lézine, A.-M., Holl, A.F.-C., Lebamba, J., Vincens, A., Assi-Khaudjis, C., Février, L., Sultan, E., 2013. Temporal relationship between Holocene human occupation and vegetation change along the northwestern margin of the Central African rainforest. C. R. Geoscience 345 (7-8) 327-335.

Méroc, L., 1967. Circonscription de Midi-Pyrénées, section Haute-Garonne. Gallia Préhistoire 10 (2) 339-411.

Pardé, M., 1935. Le régime de la Garonne. Rev. Geogr. Pyr. S. O. 6, 105-262. Rieucau, L., 1971. Des arbres fossiles dans la basse plaine de la moyenne Garonne. C. R. Somm. Soc. géol. Fr. 6, 317-318.

Salvador, P.-J., 1991. Le thème de la métamorphose fluviale dans les plaines alluviales du Rhône et de l'Isère : bassin de Malville et ombilic de Moirans (Bas-Dauphiné). Thèse. Univ. Lyon 3, 498 p.

Schumm, S.A., 1977. The Fluvial System. Wiley, New York, 338 p.

Stange, K.M., van Balen, R.T., Kasse, C., Vandenberghe, J., Carcaillet, J. 2014. Linking morphology accros the glaciofluvial interface: a ${ }^{10} \mathrm{Be}$ supported chronology of the glacier advances and terrace formation in the Garonne River, northern Pyrenees, France. Geomorphology 207, 71-95.

Starkel, 1995. Evolution of the Vistule valley during the last 15,000 years. Polish Academy of Science, Geographical Studies, Spec. Issue, $167 \mathrm{p}$.

Striedtler, C., 1988. Le Rhin en Alsace du Nord au Subboréal. Genèse d'une terrasse fluviatile holocène et son importance pour la mise en valeur de la vallée. Bull. Assoc. Fr. Etudes Quat. 25 (1) 5-11.

Stuiver, M., Reimer, P.J., 1993. Extended ${ }^{14} \mathrm{C}$ database and revised CALIB radiocarbon calibration program. Radiocarbon 35, 215-230.

Tegel, W., Barthe, F., Kintz, C., Lauer, P., Le Saint Quino, T., Rohmer Schohn, E., Thavot, P., Jude, R., 1999. Les chênes subfossiles de la gravière d'Herrlisheim (Bas-Rhin). Étude dendrochronologique pour une contribution à l'étude de l'évolution des forêts riveraines du Rhin. Nachrichtenblatt Arbeitskreis Unterwasserarchäologie (NAU) 5, 4951.

Valette, P., 2002. Les paysages de la Garonne : les métamorphoses d'un fleuve (entre Toulouse et Castets-en-Dorthe). Thèse de Géographie. Université de Toulouse Le Mirail, 554 p. 